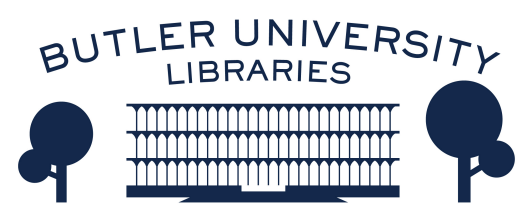

Journal of Hindu-Christian Studies

Volume 15

Article 7

January 2002

\title{
The Controversy and its Theological Implications
}

Judson B. Trapnell

Follow this and additional works at: https://digitalcommons.butler.edu/jhcs

Part of the Religion Commons

\section{Recommended Citation}

Trapnell, Judson B. (2002) "The Controversy and its Theological Implications," Journal of Hindu-Christian Studies: Vol. 15, Article 7.

Available at: https://doi.org/10.7825/2164-6279.1274

The Journal of Hindu-Christian Studies is a publication of the Society for Hindu-Christian Studies. The digital version is made available by Digital Commons @ Butler University. For questions about the Journal or the Society, please contact cbauman@butler.edu. For more information about Digital Commons @ Butler University, please contact digitalscholarship@butler.edu. 


\title{
The Controversy and its Theological Implications
}

\author{
Judson B. Trapnell
}

\section{Introduction}

THE controversy concerning evangelization and conversions in contemporary India may be productively interpreted as a conflict between stories, between what John Haught refers to as "power-bestowing narratives," or between what Gerald Larson calls "comprehensive interpretive frameworks." "These Hindu stories and Christian stories are (to use Prof. Rambachan's term) "discordant," not only with each other, but with other stories within their own traditions, thus fostering the mutual mistrust that thoroughly colors the debate. My task is to sketch four such narrative frameworks, each centered upon an image of India and corresponding to one of four communites involved in the controversy: conservative Hindu nationalists, more secularist Hindus, Evangelical Christian missionaries, and Roman Catholic theologians in India.

\section{Bharat Mata: A Conservative Hindu Story}

Whether one identifies the origin of Christianity with the legendary visit of the Apostle Thomas in the first century or with the arrival of Syrian traders in the 4th, Christianity has been a part, admittedly a very small one, of India's religious diversity for over 1600 years. Even with recent missionary successes, the estimated number of Christians remains only about $2.3 \%$ of a total population of over a billion. Neverthless, when large numbers of tribals have converted to Christianity in recent years, especially in northeastern states and in Gujarat and Orissa, some Hindus have felt threatened. ${ }^{2}$ Why? It is likely that one influence behind this sense of threat is the interpretation of Christianity as a nonindigenous religion with enduring colonialist designs that is espoused by Hindu nationalist groups, such as the Vishva Hindu Parishad (VHP) formed in 1964. In one of their founding documents, the VHP states, "The only way for the Hindu Society to save itself from the foreign onslaught of Christianity, Islam and Communism is to organise itself," lest Christians in northeastern states in particular strive to form a separate nation as Pakistan did in 1947. ${ }^{3}$ Echoing this concern in specific relation to the conversion controversy, Ex. M.P. Balraj Madhok, writing in the journal of the Arya Samaj, warns that conversion to Islam or Christianity leads to a change in loyalties for the converts whereby they become "deIndianised." With the support of groups like the VHP and Arya Samaj, efforts to reconvert Hindus are not rare. ${ }^{5}$

Were one to look for a "powerbestowing narrative" that underlies this interpretation of Christian missions, one predominant candidate is the story of India as Bharat Mata or Mother India, the sacred origin of the sanatana dharma or eternal religion.

\footnotetext{
Judson B. Trapnell is a former Assistant Professor in the Theology Department of the College of St. Benedict and St. John's University in Minnesota, U.S.A. He currently lives and writes in Charlottesville, Virginia and is the author of "Indian Sources on the Possibility of a Pluralist View of Religions," Journal of Ecumenical Studies 35/2 (Spring 1998): 210-34; and Bede Griffiths: A Life in Dialogue (Albany, NY: SUNY Press, 2001). He is currently writing a book on Abhishiktananda (Henri Le Saux).
} 
From at least the time of the Gupta restoration in the 4th $\mathrm{c}$. CE in the North, and with perhaps a consistent intention to solidify Hindu identity, India has been worshipped as a goddess. ${ }^{6}$ David Kinsley proposes that this devotional framework is still alive in the "modern cult of Bharat Mata in which all Indians are called sons or children of India and are expected to protect their mother without regard for personal hardship and sacrifice." There is even a temple in Banaras dedicated to Bharat Mata where in place of a traditional image of the goddess Devi there is a large map of India to which offerings are made. But more widespread and enduring in its influence upon Indian consciousness has been the myth of the goddess Sati whose severed body parts after an untimely death fell upon the land, sanctifying it. Kinsley concludes: "In short, the Indian subcontinent is the goddess Sati"--though not as a corpse but as a living body that is worshipped in her various forms as local goddesses.

In its more modern retellings, this narrative of the sacred land includes chapters like Dayananada Saraswati's and the Arya Samaj's concept of Àryavarta (Land of the Noble Ones); M.K. Gandhi's campaign for use of indigenous products (swadeshi) and his condemnation of Christian missions; the violent Hindu resentment sparked by Partition (1947); Rabindranath Tagore's musical adaptation of a Bengali poem (Bande Mataram, "Hail to Thee, Mother") as the country's first national anthem; numerous political debates on the rights of minorities; and the 1992 destruction of a 16th c. mosque, the Babri Masjid, in Ayodhya, supposedly on the site of Rama's birth. At present, in the perception of Hindu nationalists, conversions to Christianity, by deIndianizing segments of the population, threaten to weaken the sacredness and sovereignty of the land and to destabilize the framework of meaning that reinforces it.

\section{A Different Hindu Interpretation: India as Land of Religious Diversity and Tolerance}

Competing with the voices that condemn conversions by Christian missionaries as the underlying cause of interreligious conflicts are others that focus upon a different lesson to be learned and that seemingly draw from a different heritage. For example, in a 1999 editorial in response to the murder of Australian missionary Graham Staines and his two sons, Raghu Tagat argues that conversions are not new to India and, while linked in memory to domination by Muslims and European Christians, are now part of the country's cultural and religious wealth. $\mathrm{He}$ thus rejects Hindu nationalist efforts to assert Hindutva (Hinduness) as "not in accordance with the age-old traditions of tolerance in this country." 9 From this perspective, violence toward Christians represents more of a threat to this heritage than conversions of tribals by missionaries. No voice has been more articulate on the heritage of India than that of the Justice Wadhwa Commission of Inquiry that investigated the Staines case. The Commission concluded that such acts were an affront to a modern attitude toward religious diversity grounded in the Constitution and were thus "a blot on the fair name of India known for religious tolerance." $" 10$

These clear condemnations of the Staines murder and their connection to an image of India as a land of religious diversity and tolerance draw from a different narrative than those who center their identity upon the myth of Bharat Mata. It is the narrative of the modern struggle for independence, culminating in a Constitution along a secular model, that largely determines these norms. Pre-modern antecedents for this view of India would include the Jain teaching on anekantavada or doctrine of the many-sidedness of truth; the Bhagavad Gita's affirmation of different yogas as valid spiritualities; the 3rd century 
Buddhist emperor of north India Ashoka's official policy of religious tolerance; and the Mughal ruler of the 16th century Akbhar's interreligious explorations. Modern advocates of this view of India thus speak as though this narrative is traditional or "ageold." This perception is especially clear in the exponents of the Hindu Renaissance of the 19th and early 20th centuries-Ramakrishna, Vivekananda, Radhakrishnan, and Gandhi, to name a few.

The list of Renaissance figures and groups who contributed to the narrative of India's heritage as religiously diverse and tolerant illustrates a further point: that this perception of India is not simply a secularist one, inspired by Western models and enshrined in the Constitution. In fact, this distinctly Indian model represented for key Renaissance exponents a solution to the problem of religious plurality from which the West could also learn.

The modern yet religious impact of this narrative is especially clear in Gandhi: "I do not expect the India of my dreams to develop one religion, i.e., to be wholly Hindu or wholly Christian, or wholly Mussalman; but I want it to be wholly tolerant, with its religions working side by side with one another." that he is cited as an authority by the other Hindu model as well, especially for his denunciation of conversions as "the deadliest poison that ever sapped the fountain of truth" and "the greatest impediment to the world's progress towards peace" because this idea presumes that the truth is found more fully in one's own tradition than in another. ${ }^{12}$

These two perspectives upon India, first, as Bharat Mata, as the motherland whose national sovereignty and cultural purity must be defended from outside influences, and second, as the sacred exemplar of religious diversity and tolerance that can teach the West, constitute a dual image mirrored in Gandhi's own person.

\section{Christian Perspectives}

A different dual image of India may be discerned in the divergent narrative frameworks of Evangelical Christians and Roman Catholics in India. Shared by these two groups of Christians, however, are some of the most basic biblical foundations for missions, specifically Jesus" "great commission" to make disciples of all nations, his teaching on the spread of the Gospel to the ends of the earth prior to his second coming, and his metaphor of the harvest for evangelization (Mt. 28.18-20, 24.14, 9.35-38; cf. Mk 16.15-16). These biblical themes, repeated frequently by Christian missionary sources in India, constitute an integral part of the Christian narrative within which the debate over evangelization and conversions must be placed. For both Evangelicals and Roman Catholics, the call from Jesus to evangelize is commanding and unambiguous. The challenge, and the issue upon which these two Christian groups diverge, has been how to work within this missionary narrative in a pluralistic world of many cultures, each with their own defining religious stories.

\section{Evangelicals on India as the Setting of Spiritual Conflict}

Evangelical assessments of the current controversy about conversions are frequently grounded in the historical precedents of martyred missionaries, from Jesus on, who have accepted the inevitable risks involved in evangelization. Persecution is thus read as a necessary, even fruitful aspect of spreading the Gospel. This Evangelical perception of missions is thus set within a narrative framework of spiritual conflict, one that reflects and is reinforced by official statements of the World Evanglical Fellowship in their Lausanne Covenant (1974) and Manila Manifesto (1989). The Lausanne Coyenant's missionary call, for example, is expressed in metaphors of combat: 
We believe that we are engaged in constant spiritual warfare with the principalities and powers of evil, who are seeking to overthrow the Church and frustrate its task of world evangelization. We know our need to equip ourselves with God's armour and to fight this battle with the spiritual weapons of truth and prayer (12). ${ }^{13}$

In some of Evangelical Christianity's more extreme expressions, India in particular is associated with darkness, in theological opposition to the "light" of Christ that is coming into the world (Jn. 1.5, see also $3.19-20,8.12,9.5,12.46)$. In the language of the Southern Baptist Church's International Mission Board's pamphlet "Prayer for Hindus" (1999), "More than 900 million people are lost in the hopeless darkness of Hinduism." The head of an international Evangelical missionary group, Operation Mobilization, perceives India in related terms: "There is a massive struggle going on between good and evil in that country with the Hindu militancy that's going on, a deliberate persecution of the church."14 This perception has even prompted interpretation of recent natural disasters in India as acts of God in retaliation for the persecution of Christians. ${ }^{15}$

While some later documents from the Lausanne Committee assert a more positive appraisal of indigenous non-Christian religions, there is little to suggest that India is "storied" as anything but a country where the controversy over evangelization and conversion represents the larger spiritual warfare between Christ and Satan. ${ }^{16}$ In such a country, the sense of missionary vocation is clearly intensified. As one Indian Christian website expresses this calling: "The Church of Christ is growing. Evangelization in India is our responsibility.... Reach the unreached at any cost." $" 17$

\section{A Roman Catholic Framework: India as Context for Mutual Liberation}

Do official Vatican documents and the Pope's speeches associated with his 1999 trip to India give us clues to the narrative framework within which the debate on evangelization and conversion is occurring for Roman Catholics? Yes, but only to a limited extent. If a model of dialogue for missions is being upheld (for example in the Pope's remarks to representatives of nonChristian religions in New Delhi), so is the more traditional view of evangelization, fostering the prayer that "in the Third Christian Millenium a great harvest of faith will be reaped in this vast and vital continent." 18 The Pope acknowledges in Ecclesia in Asia that the Magisterium has needed to respond to "a certain confusion about the true nature of the Church's mission" by repeatedly emphasizing "the primacy of proclamation of Jesus Christ in all evangelizing work" (19). While there are some Indian Catholic theologians and missionaries who would agree with this "primacy of proclamation," there are others who would not, at least not without redefining it in terms more sensitive to India's interreligious situation.

In comparison to ambiguous official perceptions of India, other indigenous Catholic theologians who are formulating an Indian theology of liberation view the country differently. Their liberation perspective at once challenges the official Evangelical and Roman Catholic positions and engages more productively in dialogue with Hindu frameworks. Underlying this challenge and this capacity for dialogue is a different narrative framework, a different story.

Put succinctly, this is the "story" of "the India of the marginalized," 19 or more broadly of India as the context for mutual liberation--mutual in several senses. First, in the struggle against poverty and oppression, both "the India of the rich" and 
"the India of the poor" are liberated. Second, in its collaboration with the already existing movement among the marginalized, the Church is freed to hear the Gospel anew. Finally, in the recognition of similar ideals of socio-political as well as spiritual freedom, the numerous religions of India are also drawn together toward mutually transforming, cooperation.

To return to our broader question, what are the theological implications of this liberation framework and of its view of India for Christian evangelization and conversion? Fr. Amaladoss has suggested that an important shift in Catholic understandings of missions is taking place as a result of documents like Vatican II's Ad Gentes and Pope John Paul's Redemptoris Missio--the recognition that, in Fr. Amaladoss's words, "The Holy Spirit is active in other religions. So when I proclaim the good news among a people of a different religion I am not among a people who are by nature devilish or against the good news. ${ }^{20}$ This reperception of missions also prompts a redefining of evangelization as what promotes Gospel values, including the promotion of dialogue, justice, freedom, or community. Echoing the theme of mutuality, Fr. Amaladoss thus recharacterizes evangelization and conversion as projects that are not directed only to those outside the Catholic Church: "All of us are called to conversion.... All of us are called to a common commitment.... [W]e are asking for a common action in the pursuit of justice and fullness for all human beings."21

\section{Conclusion: Relativizing and Relating Discordant Narratives}

There is a risk involved in the relativization of frameworks for meaning inherent in the method of this paper. While this approach might help to focus the conflicts about evangelization and conversion among four communities in India, it also fosters a rather pessimistic attitude toward the future because there are few elements in life that are more resistant to change than such frameworks, as Thomas Kuhn's analysis of paradigm shifts makes apparent. Even Gandhi, who was able to relativize and even embrace divergent frameworks, was unable to prevent conflict between religious communities in his lifetime, though many would argue, Christian as well as Hindu, that he made a significant start.

This move to relativize the various narratives that frame the sides of the current conflict is admittedly easier (though not easy) for the Hindu to make than for the Christian because such a move is more compatible with the philosophical underpinnings of Hinduism as well as with the insights of its greatest exponents. For example, in a chapter entitled "A Hindu Looks at Jesus," Prof. Rambachan describes how Hinduism and Christianity actually share criteria for an authentic spirituality, prompting him to ask questions that cut to the heart of this controversy:

Does it mean that there are different ways of "reading" the same reality, and that our traditions are employing one or the other of these standpoints [what we have called narrative frameworks or stories]? Are these standpoints incompatible, and, if so, where does this incompatibility lie? Can different standpoints in some way complement each other? And does it imply that all our categories and standpoints are in some way limited and partial, and that the reality we are "reading" ultimately transcends them all? $?^{22}$

Perhaps this effort to relativize our respective stories in relation to a common truth and a common practical agenda represents the only theological strategy that will tranform this controversy from conflict to dialogue. The challenge and the opportunity set before Christians is the 
retrieval of sources that support recognition of the symbolic nature of theological expressions while fostering commitment to the divine mystery to which such expressions point.

\section{Notes}

1. John F. Haught, What is God? (Mahwah, NY: Paulist Press, 1986). Gerald James Larson, India's Agony Over Religion (Albany, NY: SUNY Press, 1995), 165-66.

2. See <censusindia.net>.

3. S.S. Apte, General Secretary, VHP, Why Vishva Hindu Parishad (<vhp.org/englishsite/ a-origin_\&_growth/whyvhp. htm>).

4. Prof. Balraj Madhok, Dangers of Religious Conversion, Vedic Light (<where is God.com/1.htm>).

5. See Chapels Burned, Tribal Christians Reconverted in Eastern India, Catholic World News $(10 / 10 / 00)$ <cwnews. $\mathrm{com} /$ news/viewrec.cfm?RefNu $\mathrm{m}=14002>$. And, Conversion of 6 Tribals to Christianity Put Off, India Times (2/23/01) $<$ news.indiatimes.com/23indu 14 .htm>.

6. David Kinsley, Hindu Goddesses: Visions of the Divine Feminine in the Hindu Religious Tradition (Berkeley, CA: University of California Press, 1986), 181.

7. Kinsley, Hindu Goddesses, 181.

8. Kinsley, Hindu Goddesses, 187.

9. Raghu Tagat, Hate, Violence Sully Country's image, editorial in The Tribune (2/8/99); $<$ tribuneindia.com/99 feb08edit.htm\#4>).

10. Memorandum of Action Taken on the Report of Justice D.P.
Wadhwa Commission of Inquiry, published on VHP website (<vhp.org >).

11. Quoted in Robert Ellsberg, ed., Gandhi on Christianity (Maryknoll, NY: Orbis Books, 1991), 59.

12. Ellsbberg, Gandhi, 65. E.g., Sita Ram Goel, History of Hindu-Christian Encounters, 2nd rev. ed. (New Delhi: Voice of India, 1996), 124-239.

13. For the full text, see $<$ gospelcom.net/lcwe/statements /covenant.html>.

14. Mission Network News (8/14/00), <gospelcom.net/

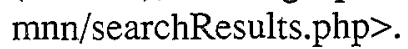

15. Mission Network News, reporting on the earthquake in Gujarat (2/14/01), <gospelcom. net/mnn/searchResults.php $>$.

16. See the Manila Manifesto 3, <gospelcom.net/lcwe/statements /manila.html>.

17. See $<$ missionsindia.org/ $>$.

18. Contrast $<$ vatican.va/holy father/john_paul_ii/travels/docu ments/hf_jpii_spe_07111999_n ewdelhi_meeting\%20other\%20r eligions_en.html>with < vatican. va/holy_father/

john_paul_ii/apost_exhorations/ documents/hf_jpii_exh0611199 9_ecclesia-in-asia_en.html $>$.

19. Felix Wilfred, Church's Commitment to the Poor in the Age of Globalization, given to the General Body Meeting of the Catholic Council of India, in Bangalore, December 1997 <sedos.org/english/wilfred1.htl> or Vidyajyoti - Journal of Theological Reflection 62.2 (1998), 86.

20. Michael Amaladoss, SJ, Dialogue and Mission (an interview with Fr. Amaladoss by the Columban Missionary 
Society, n.d.)

<indigo.ie/columban/amalad.ht $\mathrm{m}>$

21. Amaladoss, Michael, SJ, "Liberation as an Interreligious Project," in Leave the Temple: Indian Paths to Human
Liberation Felix Wilfred, ed., (Maryknoll, NY: Orbis, 1992), 168.

22. Anantanand Rambachan, The Hindu Vision (Delhi: Motilal Banarsidass, 1992), 46. 